\title{
The effect of growth hormone on milk protein gene expression in the bovine mammary gland*
}

\author{
S.A. McCoard ${ }^{1}$, N.C. Roy, B.R. Sinclair, M.H. Deighton \\ and W.C. McNabb
}

Nutrition and Behaviour Group, AgResearch Limited, Tennent Drive Palmerston North, New Zealand

\begin{abstract}
Growth hormone $(\mathrm{GH})$ treatment is known to increase milk yield but the underlying molecular mechanisms are largely unknown. The objective of this study was to profile changes in milk protein gene expression resulting from $\mathrm{GH}$ administration to lactating dairy cows. GH increased milk yield by $32 \%$ with concomitant increases in protein, fat and lactose yield. Milk composition was unaffected by treatment. Similarly, GH-treatment increased yield but not concentration of all major individual milk proteins. Expression of the key milk protein genes was not consistently regulated suggesting effects of $\mathrm{GH}$ at both transcriptional and post-transcriptional levels in the bovine mammary gland.
\end{abstract}

KEY WORDS: bovine, microarray, gene profiling, protein synthesis, growth hormone

\section{INTRODUCTION}

The mammary gland is an important organ that could be harnessed by new genetic biotechnologies and there is considerable interest in modifying milk production traits for commercial exploitation. Growth hormone $(\mathrm{GH})$ produced naturally in the pituitary gland has been used to study the mechanisms regulating lactation in ruminants (Bauman, 1992). Although GH treatment is known to stimulate milk production by up to $30 \%$ in dairy cattle, the underlying molecular mechanisms by which this occurs are unknown. GH administration may be a suitable model to identify genes controlling the rate of protein production by

\footnotetext{
* Supported by the Foundation for Research, Science and Technology and AgResearch Initiative Funds, a FRST Postdoctoral Fellowship (Sue McCoard) and is part of a larger mammary genomics Joint Venture in collaboration with Primary Industry Research Victoria, Australia

${ }^{1}$ Corresponding author: e-mail: sue.mccoard@agresearch.co.nz
} 
the mammary gland. Our hypothesis was that GH treatment would increase milk protein yield by regulating the expression of the milk protein genes.

The objective of this study was to use proprietary bovine expressed sequence tag (EST) microarray's and high performance liquid chromatography (HPLC) to identify the effect of $\mathrm{GH}$ on the profiles of the major milk protein genes and the proteins they encode.

\section{MATERIAL AND METHODS}

A slow-release formula of commercially available GH (Lactatropin ${ }^{\circledR}$, Elanco Animal Health) was administered via a single subcutaneous injection to 4 lactating Jersey cows. A further 4 Jersey cows were given a single subcutaneous injection of saline to serve as controls. All cows were housed indoors, fed a nutritionally balanced total mixed ration ad libitum and milked twice daily. Milk yield was measured and milk samples taken for compositional analysis at each milking. Six days following injection, all animals were euthanased and mammary gland samples collected. RNA was extracted (Trizol Reagent; Invitrogen), purified (RNeasy Mini Kits; Quiagen) and converted to fluorescently-labelled cDNA (Amino Allyl cDNA Labelling Kit; Ambion) and hybridized to 23.000 EST bovine microarrays. The ESTs were selected from AgResearch's proprietary database that represents approximately $80 \%$ of the bovine genome. Microarray raw data was normalized to minimize within and between slide variation (Baird et al., 2003), the log of the ratios of the intensities calculated and the data analysed using REML (Baird et al., 2002) to evaluate the treatment comparisons. Milk composition and yield parameters were analysed using the GLM procedure in SAS (Version 8e, 2001). Data are presented as least square means and standard errors of the mean (SEM).

\section{RESULTS}

Six days after treatment, GH had increased milk yield by $32 \%$ with corresponding increases in protein, fat and lactose yield (Table 1). Milk composition was unaffected by treatment (Table 1). Similarly, GH treatment increased the yield $(\sim 30 \%)$ but not concentration of all major individual milk proteins (Table 2). Expression of $\kappa$-casein, $\alpha_{\mathrm{s} 2}$-casein, $\alpha$-lactalbumin and $\beta$-lactalbumin were up-regulated while that of $\alpha_{\mathrm{s} 1}$-casein and $\beta$-casein were downregulated in response to $\mathrm{GH}$ treatment (Table 3 ). 
Table 1. Milk composition and yield in control and GH-treated cows

\begin{tabular}{lcccc}
\hline & Control & GH & SEM & P-value \\
\hline $\begin{array}{l}\text { Composition, } \% \\
\text { protein }\end{array}$ & 4.29 & 4.26 & 0.19 & NS \\
fat & 6.58 & 6.32 & 0.30 & $\mathrm{NS}$ \\
lactose & 5.23 & 5.19 & 0.07 & $\mathrm{NS}$ \\
Yield parameters, g/d & & & & \\
$\quad$ milk & 8094 & 11834 & 651 & 0.01 \\
protein & 348 & 501 & 27 & 0.01 \\
fat & 530 & 747 & 43 & 0.01 \\
$\quad$ lactose & 425 & 615 & 38 & 0.01 \\
\hline
\end{tabular}

Table 2. Milk protein concentration and yield in control and GH-treated cows

\begin{tabular}{|c|c|c|c|c|}
\hline & Control & GH & SEM & P-value \\
\hline \multicolumn{5}{|l|}{ Concentration, $\mathrm{mg} / \mathrm{ml}$} \\
\hline$\kappa$-casein & 6.98 & 6.60 & 0.47 & NS \\
\hline$\beta$-casein & 17.69 & 17.38 & 0.89 & NS \\
\hline$\alpha$-casein & 22.06 & 21.58 & 1.07 & NS \\
\hline$\alpha$-lactalbumin & 0.92 & 1.13 & 0.07 & NS \\
\hline$\beta$-lactaglobulin A & 2.56 & 2.33 & 0.10 & NS \\
\hline$\beta$-lactaglobulin B & 3.21 & 3.14 & 0.16 & NS \\
\hline total & 53.42 & 52.18 & 2.52 & NS \\
\hline \multicolumn{5}{|l|}{ Yield, g/d } \\
\hline$\kappa$-casein & 56.33 & 77.45 & 5.05 & 0.02 \\
\hline$\beta$-casein & 143.94 & 204.52 & 13.16 & 0.02 \\
\hline$\alpha$-casein & 179.23 & 254.38 & 15.90 & 0.01 \\
\hline$\alpha$-lactalbumin & 7.46 & 13.31 & 0.85 & 0.02 \\
\hline$\beta$-lactaglobulin A & 26.23 & 37.13 & 2.64 & 0.03 \\
\hline$\beta$-lactaglobulin B & 20.80 & 27.46 & 1.81 & 0.04 \\
\hline total & 433.99 & 614.27 & 37.74 & 0.01 \\
\hline
\end{tabular}

Table 3. Effect of growth hormone on milk protein gene expression relative to controls

\begin{tabular}{lcccc}
\hline $\begin{array}{l}\text { Milk protein } \\
\text { gene }\end{array}$ & $\begin{array}{c}\text { Approximate } \\
\text { \% of skim milk } \\
\text { protein }^{1}\end{array}$ & $\begin{array}{c}\text { No. EST } \\
\text { represented }\end{array}$ & $\begin{array}{c}\text { Expression } \\
\% \text { variation }\end{array}$ & P-value \\
\hline K-casein & 10.1 & 4 & $\uparrow 24-78 \%$ & 0.05 \\
$\beta$-casein & 28.4 & 7 & $\downarrow 22-90 \%$ & 0.05 \\
$\alpha_{\text {s1 }}$-casein & 30.6 & 12 & $\downarrow 16-48 \%$ & 0.05 \\
$\alpha_{\mathrm{s} 2}$-casein & 8.0 & 9 & $\uparrow 26-80 \%$ & 0.05 \\
$\alpha$-lactalbumin & 3.7 & 5 & $\uparrow 38-62 \%$ & 0.05 \\
$\beta$-lactaglobulin & 9.8 & 4 & $\uparrow 28-62 \%$ & 0.05 \\
\hline
\end{tabular}

${ }^{1}$ data derived from Miller et al. (1999) 


\section{DISCUSSION}

This study shows that the GH-stimulated increase in the major milk proteins $\alpha$ and $\beta$-casein in dairy cows is not controlled at the level of transcription. Treatment with GH increased milk yield and the yield of the major milk constituents but did not influence milk composition, consistent with previous reports (Bauman, 1992). Individual milk protein profiles showed that the GH-induced increase in protein yield is due to an increase in the yield of all milk proteins. Increased yield of $\kappa$ casein, $\alpha$-lactalbumin and $\beta$-lactalbumin was accompanied by an up-regulation of their genes. In contrast, $\beta$-casein expression, one of the major milk proteins, was down-regulated in response to GH treatment despite an increase in the yield of this protein. Interestingly, increased yield of $\alpha$-casein was accompanied by decreased expression of $\alpha_{\mathrm{s} 1}$-casein (the predominant $\alpha$-casein; Table 3) and increased $\alpha_{\mathrm{s} 2}$-casein expression. These results indicate that the involvement of GH in the regulation of milk protein synthesis involves both transcriptional and posttranscriptional events.

\section{CONCLUSIONS}

This study indicates that GH increases milk protein yield by increasing the yield of all the major milk proteins. Differential regulation of the milk protein genes indicates that $\mathrm{GH}$ regulation of milk protein synthesis involves both transcriptional regulation and post-transcriptional events. Collectively, GH treatment provides a useful model to study the molecular mechanism(s) regulating the rate of milk protein synthesis in the bovine mammary gland. Future work will involve identifying the rate-limiting steps in translational regulation.

\section{REFERENCES}

Bauman D.E., 1992. Bovine somatotropin: review of an emerging animal technology. J. Dairy Sci. $75,3432-3451$

Baird D., Johnstone P., Wilson T., 2002. The analysis of micro array data using mixed models. Workshop on the Design and Analysis of Micro array/Chip Experiments. June 2002, Melbourne (Australia)

Baird D., Johnstone P., Wilson T., 2003. Normalization of micro array data using a spatial mixed model in a REML analysis. Bioinformatics (accepted)

Miller G., Jarvis J., McBean L. (Editors), 1999. Handbook of Dairy Foods and Nutrition. $2^{\text {nd }}$ Edition. National Dairy Council, CRC Press 